This item was submitted to Loughborough's Research Repository by the author.

Items in Figshare are protected by copyright, with all rights reserved, unless otherwise indicated.

\title{
Safe haven or contagion? The disparate effects of Euro-zone crises on non- Euro-zone neighbours
}

PLEASE CITE THE PUBLISHED VERSION

https://doi.org/10.1080/00036846.2017.1358445

\section{PUBLISHER}

(c) Taylor \& Francis

\section{VERSION}

AM (Accepted Manuscript)

\section{PUBLISHER STATEMENT}

This work is made available according to the conditions of the Creative Commons Attribution-NonCommercialNoDerivatives 4.0 International (CC BY-NC-ND 4.0) licence. Full details of this licence are available at: https://creativecommons.org/licenses/by-nc-nd/4.0/

\section{LICENCE}

CC BY-NC-ND 4.0

\section{REPOSITORY RECORD}

Bird, Graham, Wenti Du, Eric Pentecost, and Thomas Willett. 2019. "Safe Haven or Contagion? the Disparate Effects of Euro-zone Crises on Non-euro-zone Neighbours". figshare. https://hdl.handle.net/2134/27173. 


\title{
Safe haven or contagion? The disparate effects of Euro-zone crises on non Euro- zone neighbours
}

\author{
Graham Bird*** Wenti Du*****Eric Pentecost**** and Thomas Willett*** \\ *Claremont Graduate University ** Claremont McKenna College \\ *** Loughborough University **** Akita International University
}

\begin{abstract}
While there have been many studies that examine contagion within the Euro-zone, this paper investigates the potential contagion from changes in the Greek sovereign risk premium over 2009-2016, as measured by the yield on 10 year government bonds, to six European countries outside of the Eurozone all of which operated a managed float against the Euro. We find evidence of contagion to potential Euro-zone ascendants (Czech Republic, Hungary and Poland), but 'flight to safety' (or safe haven) effects for the United Kingdom, Sweden and Switzerland.
\end{abstract}

JEL Classifications: C32, F34, G15

Keywords: Safe haven effects, contagion, sovereign risk premia, multivariate GARCH 


\section{Introduction}

There has been a considerable amount of research done on the effects of crises in Greece after 2009 on other members of the Euro-zone. The evidence generally suggests that the crises exerted significant contagion effects (see, for example, Mink and de Haan, 2013, Ludwig, 2014, and Metiu, 2012) although the evidence is mixed about the extent to which this reflects unjustified or "pure" contagion. Much less attention has been paid to the extent to which effects were experienced in European economies outside the Euro-zone. To address this issue we examine the effects of relative changes in the Greek sovereign risk premium on two groups of non-Euro-zone countries. The first group comprises three Central and Eastern European countries that are geographically close to the Euro-zone and that have committed themselves to become members of the zone in the future: the Czech Republic (CZ), Hungary (HU) and Poland (PO). The second group comprises three countries (United Kingdom (UK), Switzerland (CH) and Sweden (SW)), that have chosen not to be part of the Euro-zone. Of these both the United Kingdom and Switzerland are major international financial centers.

In principle, it is possible that the effects of the crises in Greece on other countries could be either positive or negative. If higher risks in the Euro-zone are expected to lead to increased risk in other countries then their risk premia should also rise. However, if following a crisis in the Euro-zone, countries outside it are seen as a safe haven then capital leaving the Euro-zone and entering non-euro countries could drive down the yield on government bonds and reduce their interest rates.

The six countries we investigate have all maintained managed floats with the euro, although the variation in the bilateral nominal exchange rates have been much greater for the United Kingdom and Switzerland than for the other four countries. ${ }^{1}$ The GBP/Euro rate and Swiss Franc/Euro rates have coefficients of variation of 20 per cent and 23 per cent respectively over the sample period from $1^{\text {st }}$ October 2009 to mid-August 2016, whereas the Swedish krona has a coefficient of variation of just under 7 per cent. All three Central and Eastern European countries have coefficients of variation of 5 percent or less. It is therefore possible to test the joint hypothesis that the degree of international financial integration and exchange rate flexibility are significant in accounting for both the sign and extent of contagion. We should emphasize that we are using the term contagion in its broad sense and do not attempt to divide it into rational and non-rational components as some studies do (see, for example, Ludwig, 2014; Giordano et al., 2013).

\footnotetext{
${ }^{1}$ Switzerland did maintain a pegged rate against the euro for part of the period in question.
} 
The rest of the paper is organized as follows. Section 2 provides a review of the relevant literature and explains how we contribute to the existing body of research. Section 3 briefly explains the model we use and the econometric methodology we adopt. Section 4 considers the times series properties of the data with a view to model selection. Section 5 presents the main results which show the statistical significance of contagion and safe haven effects from the Greek crises. Section 6 offers a few brief concluding comments.

\section{Literature review}

When applied to economics and to financial markets the concept of contagion turns out to be far from straightforward. It has been interpreted in the literature in a number of ways and has been applied to various dimensions of economic activity and to various financial assets including bonds, equities and CDS instruments. While in conventional medical usage it relates to the spread of disease, the notion of contagion in the context of economics and financial markets has been decomposed in order to examine the channels through which spreading occurs.

Contagion is often distinguished from interdependence. With a relatively high level of international economic integration, events or economic performance in one country may be expected to influence economic performance in others. By definition, open economies exhibit a degree of interdependence through their trade and financial linkages. The closer and more important these are, the greater the interdependence is likely to be. Some studies have interpreted contagion as representing a degree of comovement that goes beyond what would be expected as a consequence of interdependence (Forbes and Rigobon, 2002). The channels through which contagion in its broadest form occurs have been examined empirically by Forbes (2012) and by Stracca (2015). Forbes (2012) not only reviews the literature on the channels of contagion but discovers that countries are more vulnerable to contagion when they have a more levered banking system, greater trade exposure, weaker macroeconomic fundamentals and larger international portfolio investment liabilities. In the narrower context of the euro crisis in 2010-2012, Stracca (2015) finds that the most consistent conduits of contagion are trade exposure to the euro area, EU membership and whether a currency is pegged to the euro.

Sub-sections of the literature have examined different types of contagion and have explored different methodologies for trying to distinguish between them. In addition, the literature has examined 
contagion in the case of specific economic and financial crises, such as the East Asian crisis in 1997/98 and more recently the post 2009 crisis in the Euro-zone.

As applied to financial markets, individual studies have attempted to discriminate between wake-up call contagion, shift contagion and pure contagion. In the last of these categories the notion is that developments in one country lead to changes in market sentiment that then spread to financial markets in other countries, irrespective of the underlying fundamentals. In this sense a distinction has sometimes be made between 'rational' and 'irrational' contagion.

Much of the early literature on contagion has been well summarized by Forbes $(2012)^{2}$. She explores the different interpretations of the term and points to the empirical difficulties in distinguishing between the different types of contagion. She also critically evaluates the alternative ways of measuring contagion using probability analysis, cross market correlations, VAR models, and latent factor/GARCH models, as well as an approach based on extreme negative values. Many different statistical correlation techniques have been used in examining contagion, including dynamic conditional correlation (Engle, 2002; Chiang et al, 2007), asymmetric generalized conditional correlations (Cappiello et al. 2006), and copula functions (Kenourgiois et al. 2011; Samitas and Tsakalos, 2013). The methods of measuring contagion need to recognize important underlying issues that are associated with potential two way causality, endogeneity and omitted variables. For example, correlation does not necessarily imply contagion. A common shock that affects all countries in a similar way will result in relatively high correlation coefficients even in the absence of contagion.

In much of the literature, measures of association across financial markets do not distinguish between periods when markets are rising and when they are falling. Viewed from this perspective contagion may claim to have been found even in circumstances where economic and financial developments are improving. Contagion is defined to exist when observed associations are positive, with markets moving together in either an upward or a downward direction. In this regard the definition of contagion often used in the economics literature departs from its medical usage.

As noted above, a significant proportion of the literature on contagion focuses on the crises that have been experienced in the Euro-zone since 2009. Forbes (2012) discovers that contagion is stronger in the Euro-zone than in her full sample of countries. However, she puts this down to relatively close economic

\footnotetext{
${ }^{2}$ In the interests of brevity we do not directly cite the references that are included in the survey article by Forbes (2012) except where they are directly and specifically relevant.
} 
and financial integration rather than a particularly large degree of pure contagion. Aizenman et al (2012) use an event study framework to examine the impact of the Euro-zone crisis on developing countries. Using a similar approach Stracca (2015) investigates the effects of the crisis on a wider range of both advanced OECD countries and non-OECD emerging and developing economies. He discovers that the crisis contributed to a rise in global risk aversion and a fall in equity returns, mainly in the financial sector. In relation to what we do in this paper it is interesting to note that Stracca finds that the effect of the Euro-zone crisis of 2010-12 on government bond yields outside the euro area is generally small or insignificant, and muted when compared to the effects on equities. However, he also reports that there is a tendency for bond yields to fall after a crisis event in 'safer' countries, as measured by composite risk ratings from the International Country Risk Guide (ICRG).

Other studies of contagion in the Euro-zone have focused more specifically on the effects of the crisis in Greece on other Euro-zone countries. Using a DCC-GARCH model, Missio and Watzka (2011) test dynamic correlations between Greece's risk premium and risk premia in Portugal, Spain, Italy, the Netherlands, Belgium and Austria, as measured by the spread on ten year government bond yields compared to Germany, in the period between December 31, 2008, and December 31, 2010. They find that yield spreads in Portugal, Spain, Italy and Belgium increased along with those in Greece, but they do not offer any tests of significance.

By separating countries into peripheral and core groups within the Euro-zone and then using a spatial panel model, Muratori (2014) investigates contagion among selected Economic and Monetary Union (EMU) countries over the period between January 2007 and the end of September 2013. Contagion is once again based on the movement in ten-year government bond yield spreads and is found to exist, especially among peripheral countries.

Other studies have found more limited evidence of contagion. For example, Philippas and Siriopoulos (2013) test for contagion by focusing on bond markets in the Netherlands, Germany, Italy, Spain, Portugal and France, from January 3, 2001, to December 31, 2012. They use a time-varying spillover regime switching model and a time-varying conditional copula model. While they find that bond markets in France, Germany and the Netherlands were negatively affected by the crisis in Greece, they find no significant contagion effect on Portugal, Italy and Spain.

Pragidis et al. (2015) also look for possible contagion effects from Greece to France, Germany, Ireland, Italy, Portugal and Spain, by examining ten-year Greek government bond yields between July 2006 and 
July 2012. Using a corrected dynamic conditional correlation model, they find that the correlations between Greece and the other countries' bond yields decreased after the eruption of the Greek crisis. During the crisis period, only Irish and Portuguese bond yields were significantly correlated with the Greek bond yield.

In related work, (Bird, et al, 2017), we examine the extent to which the strength and pattern of contagion in the Euro-zone differed between the periods of the first and second Greek crises. We discover that there is evidence of contagion in both periods and that it exists for both the other crisis countries in our sample as well as for France and the Netherlands.

In this paper we add to the extant literature in a number of ways. We use a MGARCH methodology and examine a time period running from 2009 to 2016. More importantly we focus on the effects of the Greek crises on countries outside the Euro-zone. Here we distinguish between two sub groups. One comprises three non-euro countries that have stated their intention to join the Euro-zone at some point in the future (Czech Republic, Hungary and Poland). The second sub group comprises three that have not (the United Kingdom, Switzerland and Sweden). Within the latter group we include two important international financial centres; the UK and Switzerland.

\section{The Model and Methodology}

Although we do not specify a detailed model, our broad hypothesis is that, in association with crises in the Euro-zone, markets will perceive non-euro countries that are more closely aligned with the euro as being relatively more risky than those that are not. Indeed, with increasing perceived risks in parts of the Euro-zone, it seems plausible that international capital will flow not only into countries within the Eurozone that are perceived as being relatively less risky, such as Germany, but also out of the Euro-zone altogether and towards important international financial centers such as the UK and Switzerland. The consequence of this is that interest rates in these countries will decline relative to those in Greece, and perhaps even relative to Germany. In principle, therefore, crises in the Euro-zone could have either contagion effects or safe haven effects on non-euro countries.

We do not seek to distinguish between the different channels through which any observed spill-over effects occur. In principle, however, crises in the Euro-zone could have led markets to call into question the future of the euro zone itself. To the extent that crises increased the probability of the Euro-zone 
breaking apart, there could have been strong negative effects on the Euro-zone's neighbouring countries, particularly those with relatively close economic and financial ties with the Euro-zone. On the other hand, increased uncertainty about the future of the euro could also result in a movement of capital out of the euro and into other currencies, including those of neighbouring non euro countries.

In what follows we investigate whether for some non-euro countries 'safe haven' effects are exhibited rather than conventional contagion effects.

Where there are connections between crises in different countries, there is the problem of establishing the direction of causality. In the context of the Euro-zone it is possible that the connections between crises in Greece and in other Euro-zone countries ran in both directions. Given the focus of our research, these issues are of relatively limited concern. But, it still remains interesting to see whether common external factors affected all the non-euro countries in our sample in a similar qualitative way.

While reverse causation may have been important when considering crises in Greece, Ireland and Portugal, it seems much less likely that there would have been strong causal connections between changes in risk premia in countries outside the Euro-zone and in Greece. Even if such reverse causality were to exist, the question remains of whether the associations were positive or negative.

The Greek sovereign risk premium $\left(\rho_{G R}\right)$ is defined as the difference between the 10-year $\operatorname{Greek}\left(r_{G R}\right)$ and German $(\bar{r})$ long-term bond yields measured in euros, that is: $\rho_{G R t}=r_{G R t}-\overline{r_{t}}$. Similarly, as is common in the recent literature we express the interest differential for all other countries in our sample relative to the German long-term bond yield. The 'home' interest differential for these countries is defined as $\rho_{i t}=\left(r_{i t}-x_{i t}\right)-\bar{r}_{t}$ where $r_{i t}$ is the long-term sovereign bond yield of the home country $i$ in period $\mathrm{t}$ in its domestic currency and $x_{i t}$ is the expected bilateral depreciation of the home currency against the euro. In the case of a highly, but imperfectly integrated EU capital market, it is postulated that the home country and Greek asset returns and risk premia will be related such that

$$
\rho_{i t}=\beta_{0}+\beta_{1} \rho_{G R t}+\varepsilon_{i t}
$$


where $\beta_{1}$ measures the impact of a rise in the Greek risk premium on the home country risk premium ${ }^{3}$. The sign of $\beta_{1}$ is strictly ambiguous. In the case of direct contagion $\beta_{1}$ is expected to be positive as the risk spreads to other countries whose bonds are perceived as having similar risk characteristics to Greek bonds and whose economies and currencies are closely linked to the value of the euro. But the sign of $\beta_{1}$ can also be negative if the home country is deemed to be a safe haven. In this case investors flee from euro-denominated assets and purchase home country bonds denominated in other currencies. If this capital flow is sufficiently large it will raise the price of home country bonds and lower their yields. Unless Germany's interest rates for some reason, and to a greater extent, fall by more this will reduce the interest differential. In such cases the implication is that, in search of greater safety, more funds would be diverted to countries outside the Euro-zone than to Germany.

Such changes in market perceptions would be likely to have an immediate effect on exchange rates, but not necessarily on expected future changes. Unlike the risk free case where uncovered interest parity would imply that any differentials in interest rates would be offset by expected changes in exchange rates, where differentials only reflect expectations of default risk there would be no further expected changes in the spot exchange rate. Of course expectations may not be fully efficient, so in imperfect markets the initial changes in exchange rates could generate expectations of further changes or of reversals. However, for the model tested here whether the euro is ex ante expected to depreciate, appreciate or remain the same against outside countries is unimportant, as what matters is the total risk premium. So the risk premia of assets which are perceived to exhibit similar risk characteristics as Greek bonds will rise with the Greek risk premium $\left(\beta_{1}>0\right)$. The interest differential for assets which are deemed to be relatively less risky will move inversely with the Greek premium $\left(\beta_{1}<0\right)$. Such an inverse relationship would be consistent with a safe haven effect. To allow for possible expected changes in exchange rates, and in addition to our base case of no changes, we also provide a set of estimates where the actual change in the following day is assumed to have been expected. ${ }^{4}$

The interest differential with respect to Germany is often referred to as the risk premium. For the crisis countries themselves this seems appropriate as German bonds are frequently taken as the low risk

\footnotetext{
${ }^{3}$ Equation (1) collapses to uncovered interest rate parity in the very special case where $\beta_{0}=0$ and $\beta_{1}=1$, although this parity condition is not central to the analysis here.

${ }^{4}$ Of course there are many other ways to proxy expectations but since the expectations are not crucial to the analysis we limit ourselves to this one measure. As predicted we find that using this proxy does not substantially affect the results.
} 
benchmark. When countries outside of the euro zone are investigated, however, interest differentials against Germany can also reflect changes in risk free, or more accurately, low risk, rates in those countries. Particularly where we find interest rates to fall, such as in the UK, it seems unlikely that this was primarily because perceptions had become that the UK was less risky. Rather, capital inflows from the countries perceived to have had increases in risk would bid up bond prices and lower interest rates. Thus we refer to the effects on interest differentials rather than risk premia although, for countries where the differentials increase rather than fall, the changes may mainly result from changes in risk premia. Thus, for these countries, we will still often refer to risk premia.

While interest rates in Germany fell substantially over the period it seems likely that this was because of slow economic growth and the flooding of markets with liquidity by the European Central Bank, rather than because of a perception that Germany had become less risky in absolute as opposed to relative terms. Indeed, in absolute terms it seems more likely that Germany would have been perceived as riskier than before the crisis, given Germany's heavy private sector financial exposure to Greece and the likely consequences of a possible breakup of the euro zone. Therefore, it seems plausible that capital flight from the crisis countries would go not only into the 'safer' countries within the euro zone, but also to 'safe' countries outside the zone.

To estimate the interest differential model as specified in (1) the error term, $\varepsilon_{i t}$, is assumed to have a mean of zero, but a time-varying variance such that $\varepsilon_{t} \square N\left(0, H_{t}\right)$. This is in recognition of the fact that not only are the errors very unlikely to exhibit constant variance, but also the asset returns may exhibit volatility clustering, whereby the current level of volatility is positively related to its level in the immediately preceding periods. The model we use is therefore in the MGARCH class of models. We use the dynamic conditional correlation (DCC) method proposed by Engle (2002), which has the advantage of dealing directly with heteroskedasticity, as well as being able to estimate multiple country risk premia without adding too many parameters.

The multivariate conditional variance is specified as:

$$
H_{t}=D_{t} R_{t} D_{t}
$$

where $D_{t}$ is the $(n \times n)$ diagonal matrix of time varying standard deviations from univariate GARCH models with $\sqrt{h_{i i, t}}$ on the $\mathrm{i}^{\text {th }}$ diagonal, and $i=1,2, \cdots, n ; R_{t}$ is the $(n \times n)$ time-varying correlation 
matrix. The DCC model, following Engle (2002), can be estimated using a two-stage approach to maximize the log-likelihood function. If we let $\theta$ denote the parameters in $D_{t}$ and $\phi$ the parameters in $R_{t}$ then the log-likelihood function is:

$$
l_{t}(\theta, \phi)=\left[-\frac{1}{2} \sum_{t=1}^{T}\left(n \log (2 \pi)+\log \left|D_{t}\right|^{2}+\varepsilon_{t}^{\prime} D_{t}^{-2} \varepsilon_{t}\right]+\left[-\frac{1}{2} \sum_{t=1}^{T}\left(\log \left|R_{t}\right|+u_{t}^{\prime} R_{t}^{-1} u_{t}-u_{t}^{\prime} u_{t}\right)\right]\right.
$$

where $u_{t}$ is the $(n \times n)$ matrix of risk premium residuals transformed by their standard deviations, from the univariate stage of the estimation, such that an individual element is $u_{i, t}=\varepsilon_{i t} / h_{i i, t}^{-1 / 2} \cdot{ }^{5}$

\section{The Data Set and Descriptive Statistics}

The model is estimated using daily data from $1^{\text {st }}$ October 2009 until $12^{\text {th }}$ August 2016 which, allowing for weekends and bank holidays, gives 1,746 observations for estimation. Daily 10-year sovereign bond yields were taken from investing.com and daily spot exchange rate data from the ECB website, for all six 'home' countries plus Greece. Exchange rate expectations were computed to reflect the actual ex post change in the exchange rate the following day, so that $\left.\left.x_{t}=\left(\left(E_{t} e_{t+1} / e_{t}\right)-1\right)\right) \times 100=\left(\left(e_{t+1} / e_{t}\right)-1\right)\right) \times 100$ where $e_{t}$ is the spot exchange rate and $E_{t}$ is the expectations operator at time period $t$. Consistent with most of the literature on the Euro-zone crisis we investigated the full period rather than breaking it down into sub periods. ${ }^{6}$

Table 1 presents the summary descriptive statistics of the variables. These show that the Greek risk premium is very much higher, and has a very much larger standard deviation than the other countries in the sample. Switzerland on average has a lower 10-year bond yield than Germany, but also exhibits much higher kurtosis and skewness than the other sample countries. Skewness and kurtosis are higher

\footnotetext{
${ }^{5}$ Lee and Long (2009) propose extending the DCC M-GARCH model by additionally allowing dependence between the uncorrelated residuals through a copula function, to model the dependence structure of a multivariate distribution separately from the marginal distribution functions. This extension, however, is inappropriate, as we treat the Greek risk premium as exogenous and estimate the dependence of the six selected countries' interest rate differentials on the Greek risk premium.

${ }^{6}$ In other work (Bird et al, 2017) we have identified two Greek crises in the period 2009-15 and find that contagion across other crisis countries in the Euro-zone, as well as economically stronger Euro-zone countries occurred in the aftermath of both of them.
} 
for all countries when ex post expected exchange rate changes are taken into account, although for both the United Kingdom and Sweden the skew becomes negative.

Table 2 presents the time series properties of the data. These show that, apart from Switzerland, and with static exchange rate expectations, the country interest differentials are stationary. In the interest differential measure that excludes exchange rate movements, a drift term was included in the stationarity test to capture any random drift induced by excluding the change in the exchange rate. Because the interest differentials are stationarity $\mathrm{I}(0)$ processes they cannot be cointegrated.

Table 3 reports the Granger causality tests under both constant and changing exchange rates. With a constant exchange rate, no single country interest differential drives the Greek risk premium, whilst the Greek risk premium is shown to drive four of the six countries' risk premia. This suggests that our assumption that changes in the Greek risk premium are exogenous is supported in four of the six cases. Allowing for exchange rate changes strengthens this conclusion, with only the UK's risk premium not being Granger-caused by the Greek risk premia. Although this may initially appear inconsistent with a safe haven effect as far as the UK is concerned, it may equally reflect the basic weakness of the Granger causality tests in that excluded variables can 'Granger cause' both variables, rendering the test unhelpful. In addition, in this case the fact that the data are daily, and agents may well have forwardlooking expectations, means that we cannot rule out the possibility that causality may be observed as flowing in the 'wrong' direction. On balance, however, it seems plausible to treat the crises in Greece and the related changes in the Greek risk premium as the main drivers.

\section{Econometric Results}

Table 4 shows the results when the expected exchange rate change is assumed to be zero. There is contagion from Greece to the other three Central and Eastern (CEEC) EU members' risk premia, as $\beta_{1}>0$ and is statistically significant. However, the opposite is the case for the three western European countries, as $\beta_{1}<0$. This we interpret as reflecting safe haven or 'flight to safety' effects. Table $5 \mathrm{~A}$ shows a very similar set of results when exchange rate changes are incorporated into the estimations. ${ }^{7}$

\footnotetext{
${ }^{7}$ Gebka and Karoglou (2013) report a positive correlation between stock returns in Greece and the UK, Germany and France. As mentioned in the literature review, Stracca (2015) also discovers different effects of the euro crisis on equities and bond yields. However, this finding is not necessarily inconsistent with our findings since as Forbes
} 
In addition, in both versions of the model, the absolute values of the $\beta_{1}$ coefficients are smaller for the three advanced economies than for the three CEEC economies, suggesting that the offsetting exchange rate changes are larger in these economies. Moreover, the $\beta_{1}$ coefficients are very similar in size under both expectations scenarios, suggesting that the actual next day depreciation of the euro is not an important element in the transmission of changes in the Greek risk premium to other EU member states, as well as Switzerland.

Furthermore, by comparing the final columns of Tables 4 and 5 a, it seems that with static exchange rate expectations, the effects of any shock persist longer in every case (except for Switzerland). This may suggest that the flexibility of the nominal exchange rate is related to the persistence of the shocks, such that greater nominal exchange rate flexibility is commensurate with less persistence. The Czech Republic, Poland and Hungary, for example, have the lowest falls in persistence and the least flexible exchange rates over the sample period. By contrast, the countries with the largest falls in persistence are Sweden and the UK, which are countries with more flexible exchange rates.

Switzerland appears to be different. It has the most variable exchange rate, and yet the effect of shocks persists longer relative to the other Western European economies. Table 5a shows a rise in persistence and potential instability ${ }^{8}$. Having experimented with higher order GARCH models for Switzerland without achieving dynamic stability, we drop Switzerland from the sample and re-estimate the model. The results are shown in Table 5b. They concur with those presented in Table 4. There is significant contagion to the CEEC economies, but flight to safety effects for both Sweden and the UK.

In general, as far as the direction and magnitude of the contagion effects are concerned, the variability of the nominal exchange rate is not important. In terms of persistence, the adjustment to shocks is more

(2012) points out the risk properties associated with equities are different from those associated with government bonds. To some extent, equities and bonds may be asset substitutes. Bonds may be perceived as safer. Moreover, in as much as the stocks of multinational companies are traded in stock markets, share prices on the London stock exchange may reflect the poorer economic prospects of Euro-zone countries in the aftermath of crises.

${ }^{8}$ Switzerland underwent major changes in its exchange rate policy over the sample period. Although its exchange rate showed the greatest variability against the euro over the whole sample period there have been periods of stability and great variability. Between $1^{\text {st }}$ October 2009 and mid August 2011 the Swiss franc appreciated against the euro by some 40 per cent. Between February 2012 and December 2014 the Swiss franc was basically pegged against the Euro although this was followed by a very sharp appreciation of some 18 per cent between early December 2014 and the end January 2015. These sudden shifts perhaps explain the increased persistence and potential instability of the Swiss results under forward-looking expectations. Given the importance of Switzerland as a financial centre however, it is important to retain it in the sample, especially since, as noted above, exchange rate volatility is not essential for our contagion hypothesis. 
quickly dissipated the more flexible is the 'home' currency against the euro. To a limited extent, exchange rate flexibility moderates the spill-over effects from the increases in the mean risk premium in Greece to the home economies.

\section{Concluding Comments}

While it has been shown elsewhere in the literature that the effects of the crises in Greece in the period following 2009 were felt in other Euro-zone countries, there has been little investigation into the effects on European economies that did not belong to the Euro-zone. The results reported in this paper show that there was contagion to other EU member states that had stated their intention of acceding to membership of the Euro-zone, despite the fact that these countries generally had a degree of exchange rate flexibility vis-a-vis the euro. Probably more important was that these countries were not viewed as providing particularly safe assets. Thus they could be negatively affected by a general flight to safety. In sharp contrast, in the cases of the UK and Switzerland, and to a lesser extent Sweden, there seem to have been safe haven effects associated with the crises in Greece.

There remain a number of interesting aspects of the Greek and Euro-zone crises to explore in more detail. For example, to what extent do the patterns of flights to safety change over different stages of the crises and through what mechanisms do they emerge. To explain the patterns it would be helpful to gain a better understanding of the motivations behind capital movements and the extent to which they are influenced by economic and behavioural factors. However, an examination of these issues lies beyond the scope of this paper. ${ }^{9}$ In contemplating the channels of contagion our results can, however, be usefully interpreted in the context of the existing literature which emphasizes trade and financial exposure to the euro area. For example, it may be posited that the banking systems of the Czech Republic, Hungary and Poland were perceived by markets as being more vulnerable, albeit perhaps indirectly, to Greek default and to the possibility of a collapse of the Euro-zone as a whole. Again, a detailed examination of the channels of contagion and safe haven effects identified in this paper is a subject for further research.

\footnotetext{
${ }^{9}$ Bird et al (2017b) provide a preliminary empirical investigation of the extent to which the movements in risk premia during the Euro-zone crisis straddling the period 2009-2015 are consistent with the assumption that markets are efficient. They discover that while the EMH makes a useful contribution, there are occasional departures from it that can usefully be accounted for by theories of behavioural finance.
} 


\section{References}

Aizenman, Joshua, Jinjarak, Y, Lee, M, and Park, D., 2012. Developing countries' financial vulnerability to the euro crisis: an event study of equity and bond markets. NBER Working Paper, No. 18028, National Bureau of Economic Research.

Bird, G., Du, W., Pentecost, E.J. and Willett, T., 2017. Was it different the second time? An empirical analysis of contagion during the crises in Greece, 2009-2015, processed.

Bird, G, Du, W. and Willett, T. 2017. Behavioral finance and efficient markets: What does the Euro crisis tell us? Open Economies Review, 28 (2), 273-295.

Cappiello, L., Engle, R.F. \& Sheppard, K., 2006. Asymmetric Dynamics in the Correlations of Global Equity and Bond Returns. Journal of Financial Econometrics, 4, 537-572.

Chiang, T.C., Jeon, B N. and Li, H. (2007). Dynamic correlation analysis of financial contagion: Evidence from Asian markets, Journal of International Money and Finance, 26, 1206-1228.

Engle, R.F., 2002. Dynamic conditional correlation: a simple class of multivariate generalized autoregressive conditional heteroskedasticity models. Journal of Business and Economics Statistics 20, 339-350.

Forbes, K.J., 2012. The "Big C": Identifying and Mitigating Contagion in The Changing Policy Landscape, 2012 Jackson Hole Symposium hosted by the Federal Reserve Bank of Kansas City, 23-87.

Forbes, K.J. and Rigobon, R. ( 2002). No contagion, only interdependence: measuring stock market comovements. Journal of Finance, 57, 2223-2261.

Jondeau, E. and Rockinger, M. (2006), The Copula-GARCH model of conditional dependencies: An international stock market application. Journal of International Money and Finance, 25, 827-853.

Gebka, B and Karoglou, M. 2013, Have the GIPSI settled down? Breaks and multivariate stochastic volatility models for, and not against, the European financial integration, Journal of Banking and Finance, 37 (9), 3639-3653.

Giordano, R., Pericoli, M., and Tommasino, P., 2013. Pure or Wake-Up-Call Contagion? Another Look at the EMU Sovereign Debt Crisis. International Finance, 16(2), 131-160.

Kenourgios, D., Samitas, A., and Paltalidis, N. (2011). Financial crises and stock market contagion in a multivariate time-varying asymmetric framework. Journal of International Financial Markets, Institutions and Money, 21 (1), 92-106.

Lee, T-H. and Long, X., 2009. Copula-based Multivariate GARCH Model with Uncorrelated Dependent Errors, Journal of Econometrics 150, 207-218.

Ludwig, A., 2014. A unified approach to investigate pure and wake-up contagion: Evidence from the Eurozone's first financial crisis. Journal of International Money and Finance 48, 125-149.

Metiu, N., 2012. Sovereign risk contagion in the Eurozone. Economics Letters 117, 35-38.

Mink, M. and de Haan, J., 2013. Contagion during the Greek sovereign debt crisis. Journal of International Money and Finance 34, 102-113.

Missio, S. and Watzka, S., 2011. Financial Contagion and the European Debt Crisis, CESifo Working paper, No. 3554

Muratori, U. 2014. Contagion in the Euro Area Sovereign Bond Market, Social Sciences, 4 (1), 66-82 
Philippas, D. and Siriopoulos, C. 2013. Putting the 'C' into Crisis: Contagion, Correlations and Copulas on EMU Bond Markets. Journal of International Financial Markets, Institutions and Money, 27, 161-176.

Pragidis, I.C., Aielli, G.P., Chionis, D. and Schizas, P. et al. 2015. Contagion Effects During Financial Crisis: Evidence From the Greek Sovereign Bonds Market. Journal of Financial Stability 18,

Samitas,A. and Tsakalos, I., 2013. How can a small country affect the European economy? The Greek contagion phenomenon. Journal of International Financial Institutions and Money, 25, 18-32.

Stracca, L., 2015, Our currency, your problem? The global effects of the euro debt crisis. European Economic Review, 74, 1-13. 
Table 1: Descriptive Statistics

\begin{tabular}{lcccc}
\hline & Mean & Std Dev & Skewness & Kurtosis \\
Risk premia & 10.931 & 7.246 & 1.584 & 5.020 \\
Greece & -0.845 & 0.294 & 0.010 & 2.063 \\
Switzerland & 0.802 & 0.418 & 0.046 & 1.634 \\
United Kingdom & 0.226 & 0.251 & 0.033 & 2.161 \\
Sweden & 0.726 & 0.504 & 0.663 & 2.657 \\
Czech Republic & 4.424 & 1.258 & 0.787 & 3.051 \\
Hungary & 2.799 & 0.579 & 0.337 & 2.451 \\
Poland & & & & \\
Expectations Adjusted & & & & \\
Risk Premia & -0.827 & 0.522 & 3.144 & 76.503 \\
Switzerland & 0.804 & 0.566 & -0.051 & 3.911 \\
United Kingdom & 0.228 & 0.384 & -0.256 & 3.195 \\
Sweden & 0.721 & 0.551 & 0.714 & 3.407 \\
Czech Republic & 4.415 & 1.327 & 0.849 & 3.419 \\
Hungary & 2.797 & 0.671 & 0.430 & 3.081 \\
Poland & & & & \\
& & & & \\
\hline
\end{tabular}

Table 2: Time Series Statistics

\begin{tabular}{lcc}
\hline Risk premia & $\begin{array}{c}\text { ADF (static) } \\
\text { (with drift) }\end{array}$ & $\begin{array}{c}\text { ADF } \\
\text { (expectations) }\end{array}$ \\
Greece & -2.157 & \\
Switzerland & -0.734 & -16.813 \\
United Kingdom & -1.909 & -11.967 \\
Sweden & -2.148 & -17.213 \\
Czech Republic & -2.584 & -6.336 \\
Hungary & -1.924 & -6.674 \\
Poland & -2.275 & -8.794 \\
& & \\
Critical values at 5\% & -1.65 & -2.86 \\
\hline Notes: Ho: Country risk premia are non-stationarity
\end{tabular}


Table 3: Granger Causality Tests

Risk premia static case

\begin{tabular}{cccccc}
\hline $\begin{array}{c}\mathbf{H}_{\mathbf{o}}: \boldsymbol{\rho}_{\mathbf{i}} \text { doesn't } \\
\text { cause } \boldsymbol{\rho}_{\mathrm{GR}}\end{array}$ & $\mathbf{F}$ & $\mathbf{P r}<\mathbf{F}$ & $\begin{array}{c}\mathbf{H}_{\mathbf{0}}: \boldsymbol{\rho}_{\mathrm{GR}} \\
\text { doesn't cause } \boldsymbol{\rho}_{\mathbf{i}}\end{array}$ & $\mathbf{F}$ & $\mathbf{P r}<\mathbf{F}$ \\
$\mathrm{CH}$ & 1.116 & 0.328 & $\mathrm{CH}$ & 1.417 & 0.243 \\
$\mathrm{UK}$ & 1.768 & 0.171 & $\mathrm{UK}$ & $2.611^{*}$ & 0.074 \\
$\mathrm{SW}$ & 0.707 & 0.493 & $\mathrm{SW}$ & 1.756 & 0.173 \\
$\mathrm{CZ}$ & 2.232 & 0.107 & $\mathrm{CZ}$ & $2.630^{*}$ & 0.073 \\
$\mathrm{HU}$ & 0.147 & 0.868 & $\mathrm{HU}$ & $8.195^{* *}$ & 0.000 \\
$\mathrm{PO}$ & 3.201 & 0.041 & $\mathrm{PO}$ & $2.344^{* *}$ & 0.007 \\
$\mathrm{All}$ & $2.653^{* *}$ & 0.007 & & & \\
\hline
\end{tabular}

Risk premia (including exchange rate expectations)

\begin{tabular}{cccccc}
\hline $\begin{array}{c}\mathbf{H}_{\mathbf{o}}: \boldsymbol{\rho}_{\mathrm{i}} \text { doesn't } \\
\text { cause } \boldsymbol{\rho}_{\mathrm{GR}}\end{array}$ & $\mathbf{F}$ & $\mathbf{P r}<\mathbf{F}$ & $\begin{array}{c}\mathbf{H}_{\mathbf{0}}: \boldsymbol{\rho}_{\mathrm{GR}} \\
\text { doesn't cause } \boldsymbol{\rho}_{\mathbf{i}}\end{array}$ & $\mathbf{F}$ & $\mathbf{P r}<\mathbf{F}$ \\
$\mathrm{CH}$ & 4.311 & 0.116 & $\mathrm{CH}$ & $21.272^{* *}$ & 0.000 \\
$\mathrm{UK}$ & 1.531 & 0.465 & $\mathrm{UK}$ & 3.818 & 0.148 \\
$\mathrm{SW}$ & 0.656 & 0.720 & $\mathrm{SW}$ & $28.802^{* *}$ & 0.000 \\
$\mathrm{CZ}$ & 4.064 & 0.131 & $\mathrm{CZ}$ & $11.159^{* *}$ & 0.004 \\
$\mathrm{HU}$ & 0.221 & 0.805 & $\mathrm{HU}$ & $58.274^{* *}$ & 0.000 \\
PO & $8.095^{*}$ & 0.017 & $\mathrm{PO}$ & $24.937^{* *}$ & 0.000 \\
All & 18.319 & 0.106 & & & \\
\hline
\end{tabular}

Note: The superscripts ${ }^{* *}$ and ${ }^{*}$ denote statistical significance at the $5 \%$ and the $10 \%$ levels. 
Table 4: Estimation Results from the DCC-MGARCH model

\begin{tabular}{|c|c|c|c|c|c|c|}
\hline & \multicolumn{2}{|c|}{ Risk Premium equations } & \multicolumn{4}{|c|}{ Variance equations } \\
\hline & $b_{0}$ & $b_{1}$ & $a$ & $b$ & $c$ & Persistence \\
\hline $\mathrm{CH}$ & $\begin{array}{l}-0.706 * * * \\
(-94.64)\end{array}$ & $\begin{array}{l}-0.009 * * * \\
(-18.98)\end{array}$ & $\begin{array}{l}0.878^{* * *} \\
(34.58)\end{array}$ & $\begin{array}{l}0.013 \\
(1.41)\end{array}$ & $\begin{array}{l}0.003 * * * \\
(10.61)\end{array}$ & 0.891 \\
\hline UK & $\begin{array}{l}1.205^{* * *} \\
(102.86)\end{array}$ & $\begin{array}{l}-0.034^{* * *} \\
(-43.89)\end{array}$ & $\begin{array}{l}0.876 * * * \\
(34.10)\end{array}$ & $\begin{array}{l}0.006 \\
(0.55)\end{array}$ & $\begin{array}{l}0.004^{* * * *} \\
(8.81)\end{array}$ & 0.882 \\
\hline SW & $\begin{array}{l}0.477^{* * *} \\
(92.93)\end{array}$ & $\begin{array}{l}-0.016^{* * *} \\
(-42.78)\end{array}$ & $\begin{array}{l}0.916 * * * \\
(34.63)\end{array}$ & $\begin{array}{l}-0.018^{*} \\
(-1.84)\end{array}$ & $\begin{array}{l}0.002^{* * *} \\
(9.56)\end{array}$ & 0.898 \\
\hline$C Z$ & $\begin{array}{l}0.257^{* * *} \\
(20.18)\end{array}$ & $\begin{array}{l}0.042^{* * *} \\
(60.26)\end{array}$ & $\begin{array}{l}0.819 * * * \\
(32.36)\end{array}$ & $\begin{array}{l}0.047^{* * *} \\
(3.49)\end{array}$ & $\begin{array}{l}0.006^{* * *} \\
(9.33)\end{array}$ & 0.866 \\
\hline HU & $\begin{array}{l}2.843^{* *} \\
(149.74)\end{array}$ & $\begin{array}{l}0.124 * * * \\
(82.71)\end{array}$ & $\begin{array}{l}0.868 * * * \\
(35.44)\end{array}$ & $\begin{array}{l}-0.012 \\
(-1.23)\end{array}$ & $\begin{array}{l}0.033^{* * *} \\
(10.55)\end{array}$ & 0.856 \\
\hline PO & $\begin{array}{l}2.128 * * * \\
(175.90)\end{array}$ & $\begin{array}{l}0.054^{* * *} \\
(78.33)\end{array}$ & $\begin{array}{l}0.849 * * * \\
(33.08)\end{array}$ & $\begin{array}{l}0.023^{* *} \\
(2.02)\end{array}$ & $\begin{array}{l}0.007^{* * *} \\
(8.70)\end{array}$ & 0.872 \\
\hline
\end{tabular}

Notes: $\mathrm{LL}=9451.5$. The estimates of the mean-reverting process are $\lambda_{1}=0.3025$ (38.22) and $\lambda_{2}=0.6854$ (82.47). The persistence level of the variance is calculated as the summation of the coefficients in the variance equations $(a+b)$. The z-statistics are in parentheses. ${ }^{* * *}, * *$ and $*$ denote statistical significance at the $1 \%, 5 \%$ and the $10 \%$ levels with critical values of $2.58,1.96$ and 1.65 respectively. Risk premium equations: $\rho_{i t}=\beta_{0}+\beta_{1} \rho_{G R t}+\varepsilon_{i t}$ where $\mathrm{i}=\mathrm{CH}, \mathrm{UK}, \mathrm{SW}$, $\mathrm{CZ}, \mathrm{HU}, \mathrm{PO}$ and $\varepsilon_{t} \square N\left(0, H_{t}\right)$. Variance equations: $h_{i i t}=c_{i}+a_{i} h_{i i t-1}+b_{i} \varepsilon_{i t-1}^{2}$. 
Table 5a: Estimation Results from the DCC-MGARCH model (with Exchange Rate Expectations)

\begin{tabular}{|c|c|c|c|c|c|c|}
\hline & \multicolumn{2}{|c|}{ Risk Premium equations } & \multicolumn{4}{|c|}{ Variance equations } \\
\hline & $b_{0}$ & $b_{1}$ & $a$ & $b$ & $c$ & Persistence \\
\hline $\mathrm{CH}$ & $\begin{array}{l}-0.711^{* * *} \\
(-10.70)\end{array}$ & $\begin{array}{l}-0.010^{* * *} \\
(-4.18)\end{array}$ & $\begin{array}{l}0.878^{* * *} \\
(4.24)\end{array}$ & $\begin{array}{l}0.227 * * * \\
(5.75)\end{array}$ & $\begin{array}{l}0.013^{* * *} \\
(2.76)\end{array}$ & 1.105 \\
\hline UK & $\begin{array}{l}1.263^{* * *} \\
(22.47)\end{array}$ & $\begin{array}{l}-0.038^{* * *} \\
(-11.03)\end{array}$ & $\begin{array}{l}0.428^{* * *} \\
(8.35)\end{array}$ & $\begin{array}{l}0.216 \\
(1.34)\end{array}$ & $\begin{array}{l}0.084^{* * * *} \\
(2.70)\end{array}$ & 0.644 \\
\hline SW & $\begin{array}{l}0.459 * * * \\
(13.22)\end{array}$ & $\begin{array}{l}-0.018^{* * *} \\
(-7.48)\end{array}$ & $\begin{array}{l}0.424^{* * *} \\
(9.31)\end{array}$ & $\begin{array}{l}-0.042 \\
(-0.47)\end{array}$ & $\begin{array}{l}0.084^{* * *} \\
(6.85)\end{array}$ & 0.382 \\
\hline$C Z$ & $\begin{array}{l}0.201^{* *} \\
(2.22)\end{array}$ & $\begin{array}{l}0.043^{* * *} \\
(4.12)\end{array}$ & $\begin{array}{l}0.607 * * * \\
(7.94)\end{array}$ & $\begin{array}{l}0.114 \\
(1.03)\end{array}$ & $\begin{array}{l}0.043^{* * *} \\
(3.24)\end{array}$ & 0.721 \\
\hline HU & $\begin{array}{l}2.830 * * * \\
(21.81)\end{array}$ & $\begin{array}{l}0.134 * * * \\
(10.05)\end{array}$ & $\begin{array}{l}0.496 * * * \\
(14.87)\end{array}$ & $\begin{array}{l}0.141^{* *} \\
(1.96)\end{array}$ & $\begin{array}{l}0.221^{* * *} \\
(5.54)\end{array}$ & 0.637 \\
\hline PO & $\begin{array}{l}2.080^{* * *} \\
(34.59)\end{array}$ & $\begin{array}{l}0.060^{* * *} \\
(10.10)\end{array}$ & $\begin{array}{l}0.464^{* * *} \\
(12.35)\end{array}$ & $\begin{array}{l}0.273^{* *} \\
(3.59)\end{array}$ & $\begin{array}{l}0.064^{* * *} \\
(4.27)\end{array}$ & 0.737 \\
\hline
\end{tabular}

Notes: $L L=-3232.1$. The estimates of the mean-reverting process are $\lambda_{1}=0.3187$ (23.32) and $\lambda_{2}=0.4006$ (13.25). The persistence level of the variance is calculated as the summation of the coefficients in the variance equations $(a+b)$. The robust $z$-statistics are in parentheses. $* * *, * *$ and $*$ denote statistical significance at the $1 \%, 5 \%$ and the $10 \%$ levels with critical values of 2.58 , 1.96 and 1.65 respectively. Risk premium equations: $\rho_{i t}=\beta_{0}+\beta_{1} \rho_{G R t}+\varepsilon_{i t}$ where $\mathrm{i}=\mathrm{CH}, \mathrm{UK}$, $\mathrm{SW}, \mathrm{CZ}, \mathrm{HU}, \mathrm{PO}$ and $\varepsilon_{t} \square N\left(0, H_{t}\right)$ Variance equations: $h_{i i t}=c_{i}+a_{i} h_{i i t-1}+b_{i} \varepsilon_{i t-1}^{2}$ 
Table 5b: Estimation Results from the DCC-MGARCH model (with Exchange Rate Expectations)

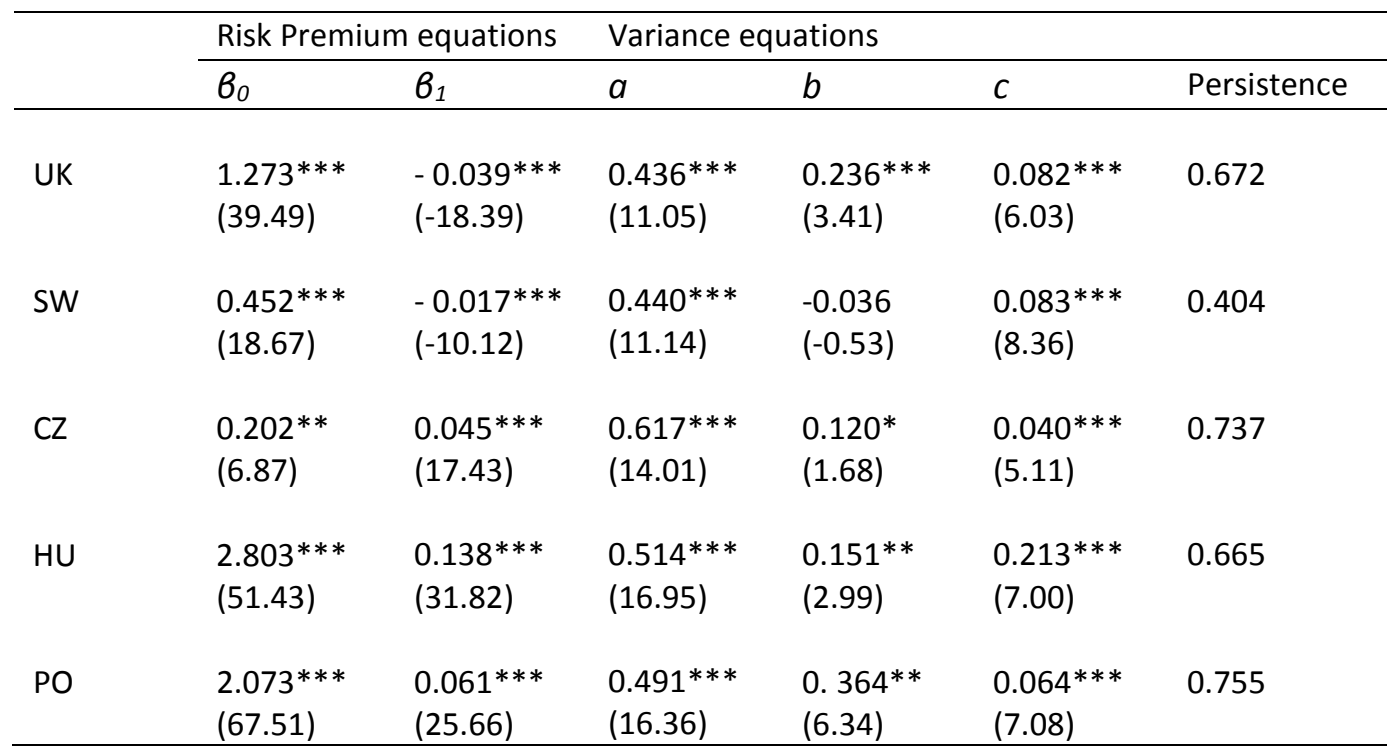

Notes: The estimates of the mean-reverting process are $\lambda_{1}=0.3190$ (21.24) and $\lambda_{2}=0.4554$ (14.95). The persistence level of the variance is calculated as the summation of the coefficients in the variance equations $(a+b)$. The robust $z$-statistics are in parentheses. ${ }^{* * *}, * *$ and $*$ denote statistical significance at the $1 \%, 5 \%$ and the $10 \%$ levels with critical values of $2.58,1.96$ and 1.65 respectively. Risk premium equations: $\rho_{i t}=\beta_{0}+\beta_{1} \rho_{G R t}+\varepsilon_{i t}$ where $\mathrm{i}=\mathrm{UK}, \mathrm{SW}, \mathrm{CZ}, \mathrm{HU}, \mathrm{PO}$ and $\varepsilon_{t} \square N\left(0, H_{t}\right)$ Variance equations: $h_{i i t}=c_{i}+a_{i} h_{i i t-1}+b_{i} \varepsilon_{i t-1}^{2}$. 